\title{
Effect of pectin extracted from citrus pulp on digesta characteristics and nutrient digestibility in broilers chickens ${ }^{1}$
}

\author{
Vanessa Karla Silva², Viviane de Souza Morita², Isabel Cristina Boleli² \\ ${ }^{1}$ Research financed by Fapesp (proc. no. 07/59891-0). \\ ${ }^{2}$ Departamento de Morfologia e Fisiologia Animal, FCAV/UNESP.
}

\begin{abstract}
The experiment was carried out to evaluate the effects of continuous ingestion of pectin on intestinal viscosity, intestinal transit time, excreta moisture content, nutrient digestibility and energy metabolism of broilers at starter and growth phases. We used 240 one-day-old Cobb male broiler chicks, distributed in a completely randomized experimental design. Treatments consisted of four concentrations of pectin $\left(0,10,30\right.$ and $\left.50 \mathrm{~g} \mathrm{~kg}^{-1}\right)$ with six replicates of 10 birds each. The ingestion of pectin supplied in the feed by broilers at the starter phase increased intestinal viscosity and intestinal transit time, reduced excreta moisture, improved the use of apparent metabolizable energy, nitrogen-corrected apparent metabolizable energy, coefficient of apparent metabolizability, coefficient of nitrogen-corrected apparent metabolizability, apparent digestibility coefficient of crude protein and organic matter; worsened calcium utilization and coefficients of apparent digestibility of dry matter; and did not influence the coefficients of apparent digestibility of crude fat, ash and phosphorus. Pectin ingestion during the growth phase increased intestinal viscosity and apparent digestibility coefficients of ash and organic matter, but decreased the dry matter, crude fat, crude protein and calcium. Intestinal transit time, energy metabolism and apparent digestibility coefficient of crude protein showed quadratic behavior according to pectin levels in the feed. Therefore, pectin ingestion by broilers at the starter phase increases intestinal viscosity and intestinal transit time, reduces excreta moisture and improves energy utilization, whereas at the growth phase nutrient digestibility is decreased.
\end{abstract}

Key Words: development, feed additive, metabolism, soluble fiber, viscosity

\section{Introduction}

Fat deposition in animals bred for meat production is an important matter for the production sector and public health, thus the efficient utilization of dietary soluble fibers aiming at the decrease of fat deposition has been the scope of several studies. Evidence about hypocholesterolemic, hypolipidemic, and hypoglycemic effects of the soluble fibers has been observed in studies with humans and other animals (Oliveira \& Sichieri., 2004; Córdova et al., 2005; Martins et al., 2005; Ramos et al., 2007; Eufrásio et al., 2009; Pinhão et al., 2010). These effects can be related to the long surface area and the amount of hydrophilic groups of the soluble fibers, such as pectin. Soluble fibers absorb water and the digesta acquires a jelly consistency, increasing in volume, which leads to resistance against peristaltism, resulting in increased viscosity and transit time of digesta (Annison \& Choct, 1994). Therefore, alterations in digesta properties may reduce nutrient digestibility and absorption (Ferreira, 1994; Back Knudsen, 1997; Freire et al., 2000; Wenk, 2001), impairing animal development (Adrizal \& Ohtani, 2002; Conte et al., 2003).
Dietary soluble fibers decrease the apparent digestibility of lipids in broilers (Smits et al., 1998) and turkeys (Sklan et al., 2003). Non-starch polysaccharides have been correlated with the variation of nutritional values of cereal grains in experiments with domestic birds (Rowe et al., 1999), because these polysaccharides decrease the digestibility of starch, protein, fat, and mineral salts (Choct \& Annison, 1990; Choct et al., 1996).

The use of new additives in feed should not cause negative effects on animal performance and on cost-benefit analysis; otherwise the use of these substances would be economically unfeasible. Composition, processing (Larbier \& Leclerq, 1994) and other factors, such as age, genotype and sex of the animals (Nir, 1988; Doeschate et al., 1993; Huang et al., 2005) influence digestibility of diets.

Alterations according to different levels of pectin supplied in feed on digesta viscosity, transit time and excreta moisture in broilers were assessed to verify if they explain the changes in metabolizable energy and digestibility and absorption of nutrients. Also, two production phases (starter and growth) with different nutritional requirements were compared to determine the behavior of these alterations in both phases. 


\section{Material and Methods}

The experiment was conducted at the Laboratory of Poultry Science of the School of Agricultural and Veterinary Sciences of Universidade Estadual Paulista (FCAV/UNESP), Campus Jaboticabal, São Paulo, Brazil, from July to August 2008.

Two hundred and forty 1-day-old Cobb male broiler chickens were obtained from a commercial hatchery. In order to homogenize replicates and treatments, chicks were individually weighed and distributed according to four levels of pectin $\left(0,10,30\right.$ and $\left.50 \mathrm{~g} \mathrm{~kg}^{-1}\right)$ within a completely randomized experimental design. Treatments for starter phase (from 1 to $21 \mathrm{~d}$ of age) were composed of six replicates with 10 birds each (total of 60 birds per treatment); broilers were housed in battery cages equipped with heating system using light bulbs, nipple drinkers and gutter-type feeders. Treatments for growth phase (from 22 to $34 \mathrm{~d}$ of age), were the same, but composed of six replications with nine birds each (54 birds per treatment); broilers were housed in cages with drinker and gutter feeder under natural light only. Water and feed were provided ad libitum from the 1 st $\mathrm{d}$ of age.

Diets (Table 1) were adjusted for each rearing phase according to recommendations by Rostagno et al. (2005). All experimental diets were equal in calories and nutrients so as to allow the evaluation of pectin, avoiding misunderstandings and/or interference of effects from other feed upon evaluated parameters.

Chicks were vaccinated against Marek and Bouba diseases in the incubatory. After housing, birds were vaccinated against Gumboro and Newcastle diseases on the 8th day and Gumboro again on the 18th day.

Temperature and relative humidity of the poultry house were measured and recorded during the whole experimental period with a digital thermo-hygrometer located at the center of the poultry house. Maximum and minimum temperature $\left({ }^{\circ} \mathrm{C}\right)$ and relative humidity (\%) were recorded twice each day and the following means were found from the 1 st to 5 th week: $30.1 \pm 3.5,28.4 \pm 1.40$, $26.2 \pm 1.04,25.2 \pm 1.1,24.3 \pm 1.02^{\circ} \mathrm{C}$; and $36.0 \pm 4.94,36.2 \pm 1.92$, $32.0 \pm 1.75,37.3 \pm 2.8$ and $34.0 \pm 1.8 \%$, respectively.

Excreta from starter (from 14 to $18 \mathrm{~d}$ of age) and growth phases (from 27 to $31 \mathrm{~d}$ of age) were totally collected with metal trays covered with plastic and placed under the cages, twice a day - early in the morning and late in the afternoon. Iron oxide was added at $0.01 \mathrm{~g} \mathrm{~kg} /$ diet on the first and the last day of collection as marker to determine the beginning and the end of total excreta collection. Samples were placed in plastic bags, identified weighed and frozen. Feed intake of each replicate was calculated by subtracting the amount of feed that was not consumed from that supplied for the broilers. Excreta from each replicate were melted and homogenized. Then, two samples from each replicate (200 g/sample) were placed in aluminum containers and maintained in a forced air laboratory oven $\left(55^{\circ} \mathrm{C}\right)$ during 72 hours to dry. Afterwards, samples were ground in Wiley mill for analysis.

Feed and excreta were analyzed in duplicates to assess the levels of nutrients and energy. Dry matter was obtained in laboratory oven at $100{ }^{\circ} \mathrm{C}$ during 16 hours; total nitrogen was obtained by the Kjeldahl method (Nx6.25); and crude fat was determined by extraction with petroleum ether and ashes in muffle furnace at $600{ }^{\circ} \mathrm{C}$ during 4 hours. Mineral solution was obtained from ashes according to recomendations of Silva \& Queiroz (2002), minerals were decomplexed by adding chloride acid, which allowed for calcium and phosphorous analysis. Calcium was determined by atomic absorption in a GBC equipment (932AA, Analitica, São Paulo, Brazil) and phosphorus with a spectrophotometer (B-395, Micronal, São Paulo, Brazil). Gross energy was determined by oxygen bomb calorimeter (Parr, Modelo - 1271, Moline, USA).

Metabolizable energy was calculated using the equations proposed by Matterson et al. (1965) and the apparent digestibility coefficient (ADC) of the nutrients was calculated by:

$A D C$ nutrient $=\frac{\% \text { Nutrient ingested }-\% \text { Nutrient excreted }}{\text { DM ingested }} * 100$

Intestinal transit time corresponded to the time from feed ingestion until full elimination of excreta, both marked with iron oxide (as described previously). This parameter was evaluated at 14 and $27 \mathrm{~d}$ of age in each experimental replicate.

Intestinal viscosity at 20 and $34 \mathrm{~d}$ of age was determined with one bird from each replicate, which was euthanized by cervical displacement for collection of digesta content from jejunum. Samples were centrifuged at 15,000 rpm for 15 minutes, then $0.5 \mathrm{~mL}$ of supernatant was separated and left to heat at $25^{\circ} \mathrm{C}$. Viscosity was measured in duplicates with digital viscometer (Brookfield DV-III) with a spindle CP-40.

Experimental results were analyzed to verify the presence of outliers, the attendance to presumptions of normality for studentized errors and the homogeneity of variances. Data was subjected to analysis of variance using the GLM procedure of software SAS ${ }^{\circledR}$ (Statistical Analysis System, version 9.1) to determine the adequate regression equations according to the levels of pectin supplementation. Correlation coefficients $\left(\mathrm{r}^{2}\right)$ between the intestinal transit 
Table 1 - Composition and nutrients of the experimental diets $\left(\mathrm{g} \mathrm{kg}^{-1}\right.$ as fed)

\begin{tabular}{|c|c|c|c|c|c|c|c|c|}
\hline \multirow{3}{*}{ Ingredients } & \multicolumn{4}{|c|}{ Starter phase } & \multicolumn{4}{|c|}{ Growth phase } \\
\hline & \multicolumn{8}{|c|}{ Pectin } \\
\hline & 0 & 10 & 20 & 50 & 0 & 10 & 30 & 50 \\
\hline Soybean meal & 369.2 & 369.2 & 369.2 & 369.2 & 309.5 & 309.5 & 309.5 & 309.5 \\
\hline Soybean oil & 57.5 & 57.5 & 57.5 & 57.5 & 74.0 & 74.0 & 74.0 & 74.0 \\
\hline Dicalcium phosphate & 19.0 & 19.0 & 19.0 & 19.0 & 16.4 & 16.4 & 16.4 & 16.4 \\
\hline L-lysine- HCL (78\%) & 6.1 & 6.1 & 6.1 & 6.1 & 3.0 & 3.0 & 3.0 & 3.0 \\
\hline DL-methionine (99\%) & 3.4 & 3.4 & 3.4 & 3.4 & 4.0 & 4.0 & 4.0 & 4.0 \\
\hline L-threonine & 1.4 & 1.4 & 1.4 & 1.4 & 0.8 & 0.8 & 0.8 & 0.8 \\
\hline Antioxidant $^{1}$ & 0.5 & 0.5 & 0.5 & 0.5 & 0.5 & 0.5 & 0.5 & 0.5 \\
\hline Vitamin and mineral premix ${ }^{2}$ & $5.0^{2}$ & $5.0^{2}$ & $5.0^{2}$ & $5.0^{2}$ & $5.0^{3}$ & $5.0^{3}$ & $5.0^{3}$ & $5.0^{3}$ \\
\hline Inert $^{4}$ & 50 & 40 & 20 & 0.0 & 50 & 40 & 20 & 0.0 \\
\hline Calcium & 9.2 & 9.2 & 9.2 & 9.2 & 8.1 & 190.2 & 190.2 & 190.2 \\
\hline Available phosphorus & 4.6 & 4.6 & 4.6 & 4.6 & 4.0 & 8.1 & 8.1 & 8.1 \\
\hline Sodium & 2.2 & 2.2 & 2.2 & 2.2 & 2.0 & 4.0 & 4.0 & 4.0 \\
\hline Digestible lysine & 15.0 & 15.0 & 15.0 & 15.0 & 11.3 & 2.0 & 2.0 & 2.0 \\
\hline Digestible methionine & 6.3 & 6.3 & 6.3 & 6.3 & 6.6 & 11.3 & 11.3 & 11.3 \\
\hline Digestible lysine + methionine & 9.1 & 9.1 & 9.1 & 9.1 & 9.1 & 6.6 & 6.6 & 6.6 \\
\hline \multirow[t]{2}{*}{ Digestible threonine } & 8.3 & 8.3 & 8.3 & 8.3 & 7.0 & 9.1 & 9.1 & 9.1 \\
\hline & \multicolumn{8}{|c|}{ Analyzed nutritional composition } \\
\hline Dry matter & 898.6 & 897.8 & 903.3 & 891.1 & 892.3 & 894.6 & 880.9 & 888.0 \\
\hline Humidity & 101.4 & 102.2 & 96.7 & 108.8 & 101.7 & 105.4 & 119.0 & 112.0 \\
\hline Crude protein & 248.4 & 249.8 & 248.5 & 243.3 & 218.2 & 214.1 & 219.1 & 217.1 \\
\hline \multicolumn{9}{|c|}{ 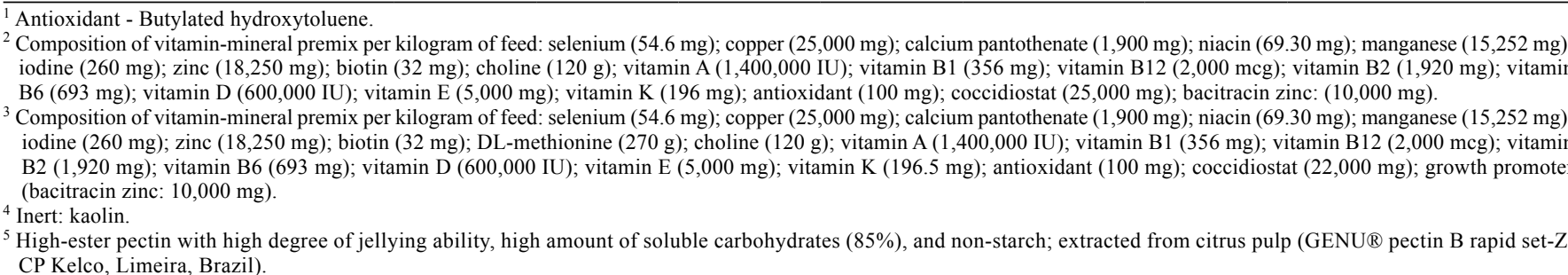 } \\
\hline
\end{tabular}

time, the intestinal viscosity and the excreta moisture content and the other variables analyzed were obtained using the PROC CORR procedure of software $\mathrm{SAS}^{\circledR}$. The statistical significance level was $\alpha=0.05$.

\section{Results}

In the starter phase, intestinal transit time (ITT), intestinal viscosity (IV), excreta moisture content (EMC), apparent metabolizable energy (AME), nitrogen-corrected apparent metabolizable energy (AMEn), apparent coefficient of metabolizability (ACM), nitrogen-corrected apparent coefficient of metabolizability (ACMn) and apparent digestibility coefficient (ADC) of: dry matter (ADCDM), crude protein $(\mathrm{ADCCP})$, organic matter $(\mathrm{ADCOM})$ and calcium $(\mathrm{ADCCa})$ were significantly influenced $(\mathrm{P}<0.05)$ by the pectin level for this phase of development in broilers (Table 2).

Intestinal transit time and IV presented significant linear increase $(\mathrm{P}<0.05)$ according to the pectin levels in the diet, whereas EMC decreased linearly. Significant linear behavior was observed for AME, AMEn, ACM and ACMn $(\mathrm{P}<0.05)$ according to the levels of pectin, thus these energy values and coefficients increased as the pectin levels increased.

The results indicated a quadratic effect for ADCDM and a crescent linear effect for ADCOM and ADCCP as a function of pectin concentration. However, ADCCF, ADCA 
and ADCP were not influenced $(\mathrm{P}>0.05)$ by the levels of ingested pectin (ADCCF: $\mathrm{y}=80.22$, ADCA: $\mathrm{y}=32.45$; ADCP: $y=59.95)$ and ADCCa presented significant linear effect $(\mathrm{P}<0.05)$, decreasing as the pectin levels increased (Table 2).

In the growth phase (Table 3), the ITT presented significant quadratic effect $(\mathrm{P}<0.05)$ as a function of pectin levels, and the highest ITT values were obtained with the ingestion of levels between 10 and $30 \mathrm{~g}$ pectin $/ \mathrm{kg}$ of diet (Table 4). Results of IV and EMC presented significant linear and quadratic effect $(\mathrm{P}<0.05)$, respectively, as a function of the pectin levels. The lowest percentage of EMC occurred with the ingestion between 10 and $30 \mathrm{~g}$ pectin $/ \mathrm{kg}$ diet.
The AME, AMEn, ACM and ACMn values were described by a significant quadratic effect $(\mathrm{P}<0.05)$ as a function of the pectin levels in the feed. The highest values of AME and AMEn were obtained between 10 and $30 \mathrm{~g}$ pectin $/ \mathrm{kg}$ diet. When pectin levels were below 1\%, ACM and ACMn presented the highest values.

The ADCDM, ADCCF and ADCCP values increased linearly $(\mathrm{P}<0.05)$ as a function of the pectin levels, whereas for the values of ADCOM, a quadratic behavior could be observed $(\mathrm{P}<0.05)$ and the levels below $10 \mathrm{~g}$ pectin $/ \mathrm{kg}$ diet resulted in the highest ADCOM. Linear behavior $(\mathrm{P}<0.05)$ was be observed for ADCA and ADCCa and quadratic behavior for ADCP as a function of pectin levels. The

Table 2 - Means and regression equations of the pectin levels in the feed considering the parameters for the starter phase

\begin{tabular}{|c|c|c|c|c|c|c|c|c|}
\hline & \multicolumn{4}{|c|}{$\operatorname{Pectin}\left(\mathrm{g} \mathrm{kg}^{-1}\right)$} & \multirow{2}{*}{ Regression equations } & \multirow{2}{*}{$r^{2}$} & \multirow{2}{*}{ P-value } & \multirow{2}{*}{$\mathrm{CV}(\%)$} \\
\hline & 0 & 10 & 30 & 50 & & & & \\
\hline ITT & 149.83 & 141.68 & 168.83 & 160.00 & $Y=0.0004 x+1.68$ & 0.2801 & 0.0135 & 5.22 \\
\hline IV & $5.10^{*}$ & 5.34 & 69.03 & 271.30 & $Y=0.13 x+1.11 *$ & 0.8398 & $<0.0001$ & 8.07 \\
\hline EMC & 0.761 & 0.752 & 0.731 & 0.712 & $Y=-0.010 x+0.762$ & 0.7757 & $<0.0001$ & 1.53 \\
\hline AME & $2,856.83$ & $3,026.74$ & $3,213.30$ & $3,099.90$ & $Y=162.74 x+2.867 .46$ & 0.3954 & 0.0129 & 3.41 \\
\hline AMEn & $2,669.51$ & $2,828.21$ & $2,986.09$ & $2,911.48$ & $Y=139.96 x+2.682 .65$ & 0.4075 & 0.0179 & 3.45 \\
\hline CAM & 0.699 & 0.732 & 0.775 & 0.748 & $Y=-0.035 x+0.701$ & 0.3091 & 0.0361 & 4.40 \\
\hline ADCOM & 0.813 & 0.841 & 0.905 & 0.948 & $Y=0.033 x+0.811$ & 0.8951 & 0.0008 & 1.48 \\
\hline $\mathrm{ADCCP}$ & 0.563 & 0.593 & 0.682 & 0.668 & $Y=0.049 x+0.558$ & 0.4994 & 0.0289 & 6.03 \\
\hline $\mathrm{ADCCF}$ & 0.8 .6 & 0.825 & 0.842 & 0.783 & $Y=0.802$ & - & 0.1284 & 9.99 \\
\hline ADCA & 0.374 & 0.253 & 0.472 & 0.486 & $Y=0.324$ & - & 0.3654 & 31.56 \\
\hline $\mathrm{ADCCa}$ & 0.648 & 0.601 & 0.583 & 0.503 & $Y=-0.026 x+0.643$ & 0.6310 & $<0.0001$ & 6.85 \\
\hline ADCP & 0.583 & 0.611 & 0.574 & 0.485 & $\mathrm{Y}=0.599$ & - & 0.2649 & 9.00 \\
\hline
\end{tabular}

Data was compared using the transformed variable * (y0.00558).

ITT - intestinal transit time (min); IV - intestinal viscosity (Centipoise); EMC - excreta moisture content (\%); AME - apparent metabolizable energy (kcal/kg); AMEn - nitrogencorrected apparent metabolizable energy ( $\mathrm{kcal} / \mathrm{kg})$; CAM - coefficient of apparent metabolizability $(\mathrm{g} / \mathrm{g})$; CAMn - coefficient of nitrogen-corrected apparent metabolizability $(\mathrm{g} / \mathrm{g}) ; \mathrm{ADC}$ - apparent digestibility coefficient: DM - dry matter $(\mathrm{g} / \mathrm{g}) ; \mathrm{CF}$ - crude fat $(\mathrm{g} / \mathrm{g}) ; \mathrm{CP}$ - crude protein $(\mathrm{g} / \mathrm{g}) ; \mathrm{OM}$ - organic matter $(\mathrm{g} / \mathrm{g}) ; \mathrm{A}$ - ash $(\mathrm{g} / \mathrm{g}) ; \mathrm{Ca}$ - calcium $(\mathrm{g} / \mathrm{g}) ;$ $\mathrm{P}$ - phosphorus $(\mathrm{g} / \mathrm{g})$.

$\mathrm{CV}(\%)$ - coefficient of variation

Table 3 - Means and regression equations of the pectin levels in the feed considering the parameters for the growth phase

\begin{tabular}{|c|c|c|c|c|c|c|c|c|}
\hline & \multicolumn{4}{|c|}{ Pectin } & \multirow{2}{*}{ Regression equations } & \multirow{2}{*}{$r^{2}$} & \multirow{2}{*}{ P-value } & \multirow{2}{*}{$\mathrm{CV}(\%)$} \\
\hline & 0 & 10 & 30 & 50 & & & & \\
\hline ITT & 162.67 & 172.17 & 172.17 & 147.83 & $Y=-3.08 x^{2}+12.40 x+162.73$ & 0.5005 & 0.0014 & 6.65 \\
\hline IV & $9.04 * *$ & 12.37 & 150.14 & 258.58 & $\mathrm{Y}=0.15 \mathrm{x}+1.28 * *$ & 0.8252 & $<0.0001$ & 8.08 \\
\hline EMC & 81.48 & 80.30 & 78.80 & 81.37 & $Y=0.40 x^{2}-2.09 x+2867.46$ & 0.6245 & $<0.0001$ & 1.07 \\
\hline AME & 3457.02 & 3373.62 & 3414.66 & 3045.34 & $Y=-26.92 x^{2}+63.76 x+3.415 .20$ & 0.5612 & 0.0289 & 4.16 \\
\hline AMEn & 3244.52 & 3154.33 & 3254.15 & 2866.97 & $Y=-28.52 x^{2}+85.08 x+3.193 .52$ & 0.5069 & 0.0006 & 4.07 \\
\hline CAM & 75.86 & 74.20 & 70.76 & 61.01 & $Y=-0.57 x^{2}-0.02 x+75.49$ & 0.8226 & 0.0191 & 4.08 \\
\hline CAMn & 71.20 & 69.37 & 67.43 & 57.83 & $Y=-0.69 x^{2}+0.77 x+70.54$ & 0.7999 & 0.0100 & 3.98 \\
\hline ADCDM & 66.80 & 66.31 & 63.25 & 57.09 & $Y=-1.95 x+67.75$ & 0.6397 & $<0.0001$ & 4.62 \\
\hline ADCOM & 82.86 & 75.89 & 74.52 & 59.28 & $Y=-4.07 x+82.17$ & 0.5179 & $<0.0001$ & 10.77 \\
\hline ADCCP & 64.92 & 65.50 & 55.69 & 50.79 & $Y=-3.16 x+66.35$ & 0.6709 & $<0.0001$ & 7.43 \\
\hline $\mathrm{ADCCF}$ & 72.86 & 72.09 & 68.17 & 60.84 & $Y=-0.42 x^{2}-0.31 x+72.84$ & 0.8094 & 0.0435 & 3.71 \\
\hline $\mathrm{ADCA}$ & 13.71 & 15.90 & 22.92 & 25.01 & $Y=2.39 x+14.00$ & 0.3951 & 0.0010 & 30.60 \\
\hline $\mathrm{ADCCa}$ & 58.89 & 60.84 & 64.18 & 61.91 & $Y=-2.11 x+61.08$ & 0.4334 & 0.0005 & 7.74 \\
\hline ADCP & 53.91 & 54.59 & 58.90 & 44.85 & $Y=-1.49 x^{2}+6.04+52.57$ & 0.6410 & $<0.0001$ & 7.28 \\
\hline
\end{tabular}

Data was compared using the transformed variable and **(y0.12674).

ITT - intestinal transit time (min); IV - intestinal viscosity (Centipoise); EMC - excreta moisture content (\%); AME - apparent metabolizable energy (kcal/kg); AMEn - nitrogencorrected apparent metabolizable energy ( $\mathrm{kcal} / \mathrm{kg})$; CAM - coefficient of apparent metabolizability (g/g); CAMn - coefficient of nitrogen-corrected apparent metabolizability (g/g); ADC - apparent digestibility coefficient: DM - dry matter (g/g) - CF - crude fat (g/g); CP - crude protein (g/g); OM - organic matter (g/g); A - ash (g/g); Ca - calcium (g/g); P - phosphorus $(\mathrm{g} / \mathrm{g})$.

$\mathrm{CV}(\%)$ - coefficient of variation. 
Table 4 - Pearson's correlation coefficients $\left(\mathrm{r}^{2}\right)$ between intestinal transit time, intestinal viscosity and excreta moisture content and the other evaluated parameters for each developmental phase of the broilers

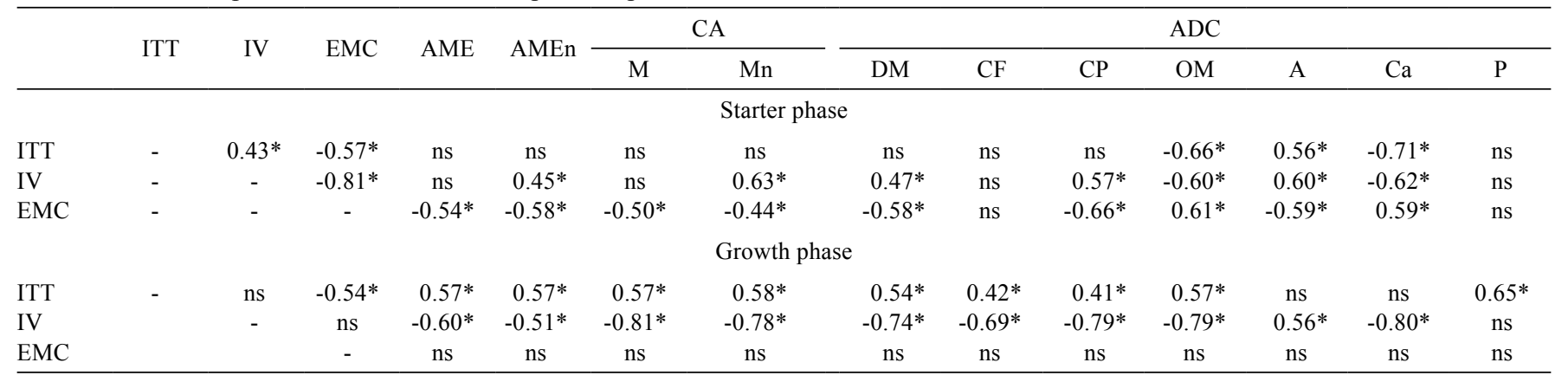

* Level of significance: $5 \%$ by $\mathrm{T}$ test. $\mathrm{n}=6$ replicates per treatment.

ns - not significant; ITT - intestinal transit time (min); IV - intestinal viscosity (Centipoise); EMC - excreta moisture content (\%); AME - apparent metabolizable energy (kcal/kg); AMEn - nitrogen-corrected apparent metabolizable energy ( $\mathrm{kcal} / \mathrm{kg})$; CAM - coefficient of apparent metabolizability (g/g); CAMn - coefficient of nitrogen-corrected apparent metabolizability (g/g); ADC - apparent digestibility coefficient: DM - dry matter (g/g) - CF - crude fat (g/g); CP - crude protein (g/g); OM - organic matter (g/g); A - ash (g/g); $\mathrm{Ca}$ - calcium $(\mathrm{g} / \mathrm{g}) ; \mathrm{P}$ - phosphorus $(\mathrm{g} / \mathrm{g})$.

apparent digestibility coefficient of organic matter increased and the ADCCa decreased with the higher pectin levels. Higher ADCP were observed with the ingestion levels from 10 and $30 \mathrm{~g}$ pectin/kg diet.

At the starter phase, IV presented positive correlation with ITT and highly negative correlation with EMC. The EMC correlated negatively with ITT.

Metabolizable energy and metabolizability coefficients did not present significant correlations with ITT, whereas with EMC, a tendency of negative correlation could be noticed. Intestinal viscosity did not show significant correlations with AME and ACM but a positive correlation could be observed with AMEn and ACMn. Correlation of ITT with ADCOM was negative, whereas with ADCDM, ADCCF and ADCCP there was no significant correlation. The apparent digestibility coefficient of dry matter and crude protein correlated positively with IV, and negatively with ADCOM. There were no significant correlations between ADCCF and IV. Excreta moisture content correlation was: negative with ADCDM and ADCCP; positive with ADCOM; and not significant with ADCCF. The apparent digestibility coefficient of ash presented positive correlation with ITT and IV, and negative correlation with EMC. The apparent digestibility coefficient of calcium correlated negatively with ITT and IV, and positively with EMC. There were no significant correlations between ADCP and ITT or IV and EMC.

At the growth phase, IV did not present correlation $(\mathrm{P}>0.05)$ with ITT and EMC. A moderate negative correlation was observed between ITT and EMC. Apparent metabolizable energy, AMEn, ACM, and ACMn showed moderate positive correlation with ITT. Intestinal viscosity presented moderate negative correlation with AME and AMEn; and high negative correlation with ACM and ACMn. There was no significant correlation $(\mathrm{P}>0.05)$ between the energy values and the EMC coefficients. The apparent digestibility coefficients of DM, CF, CP and $\mathrm{OM}$ presented a moderate positive correlation with ITT and a high negative correlation with IV. Significant correlations among the digestibility coefficients with EMC did not occur $(\mathrm{P}>0.05)$. Positive correlation between ADCP and ITT $(\mathrm{P}<0.05)$, between ADCA and IV $(\mathrm{P}<0.05)$, and high negative correlation between ADCCa and IV $(\mathrm{P}<0.05)$ were detected. However, there was no significant correlation $(\mathrm{P}>0.05)$ between ADCA, ADCCa and ITT, between ADCP and IV, and between ADCA, ADCCa, ADCP and EMC.

\section{Discussion}

This study evaluated the effect of different pectin levels in the diet on energy utilization, nutrient digestibility and mineral absorption in broilers at starter and growth phases.

In the first phase, as pectin levels in the feed were increased the IV increased and EMC decreased, which explains the high negative correlation between these parameters. Simultaneously, the ITT increased as the pectin levels increased and fiber was responsible for only $30 \%$ of variability in this parameter. The ITT correlation with IV was positive and with EMC it was negative, demonstrating their influence on ITT. The increase in ITT and IV and the decrease in EMC when the pectin levels increased can be explained by the hydration property of soluble fibers, forming jelly (Conte et al., 2003; Fietz \& Salgado, 1999; Santos Júnior, 2003; Gutkoski \& Trombetta, 1999). Thus, these three parameters presented significant correlation at the starter phase. The increase in IV was observed by several authors who used purified and soluble non-starch polysaccharide added to the diet in experiments with broilers (Jia et al., 2009), pigs (Buraczewska et al., 2007) and fishes (Amirkolaie et al., 2005; Leenhouwers et al., 2006 
and 2007), showing a similar effect in different species of vertebrates.

Energy utilization increased (AME, AMEn, ACM, and ACMn), but less than $40 \%$ could be explained by the variation in fiber levels. Concomitantly, ADCOM and ADCCP also increased, indicating that the increase in energy absorption involves higher digestibility values of organic matter, and consequently of crude protein, considering that pectin does not influence ADCCF. This fact can be reinforced by the positive correlation observed between IV and AMEn, ACMn, ADCDM and ADCCP, as well as by the absence of significant correlation between IV and AME, ACM and ADCCF. These observations evidence the pectin properties of water absorption and the ability of jelly formation (Fietz \& Salgado, 1999; Gutkoski \& Trombetta, 1999; Conte et al., 2003; Santos Júnior, 2003), which influenced AMEn, ACMn, and the digestibility of dry matter and crude protein.

Broilers presented the best apparent digestibility coefficient of organic matter (ADCOM) when the inclusion of pectin in the feed was increased. Vergara et al. (1989) described the retention time of $\mathrm{Cr}$-mordanted fiber from wheat meal (an insoluble indicator) in broilers and verified a decrease from the first until the third week of age, whereas the retention time of Cr-EDTA, another insoluble marker, increased. Those authors suggested that this result can be explained by the beginning of cecum functioning, increasing fermentation rate and causing the disappearance of the soluble fiber fraction. Benício (1996) affirmed that these variations occurred due to the quantity and type of microorganisms colonizing the gastrointestinal tract. Biochemical conditions of the digesta are a result from physiological response to the chemical composition of diet; and these conditions affect availability and concentration of substrate, and consequently the formation of products by the microbiota (Barrow, 1992). Shakouri et al. (2006) evaluated the effect of non-starch polysaccharides on microbial population at different intestinal segments and verified that the addition of pectin to the diet increased the population of anaerobic microorganisms at the proximal portion of the intestine. Langhout et al. (1999) found a higher population of anaerobic bacteria in the ileum when $30 \mathrm{~g}$ high-methoxyled pectin were added per kg of diet, whereas Wanger \& Thomas (1978) found high amounts of bacteria in all portions of the intestine. Therefore, the good use of organic matter observed at the starter phase of this study can be related to the increased number of bacteria from the gastrointestinal tract of broilers supplied with higher pectin levels.

Apparent digestibility coefficient of crude fat was not influenced by the increase of pectin levels in the feed. Ide et al. (1989) and Ikegami et al. (1990) affirmed that the nonstarch polysaccharides can influence the lipid metabolism because viscosity can increase the secretion of bile, and consequently result in loss of those acids in feces. Results from this study do not agree with Edney et al. (1989), who observed worse results for fecal digestibility of fat in rats and an increase in IV in broilers.

Apparent digestibility coefficient of ash was not altered by pectin ingestion, indicating that the influence of levels of fiber ingestion on dry matter digestibility does not involve ash digestibility at the starter phase. However, utilization of calcium decreased as pectin levels in the feed increased and no alterations in phosphorus digestibility could be observed. These results were similar to those found by Hetland \& Svihus (2001), who did not observe effect of the different types of carbohydrates on ash digestibility. However, Van der Klis et al. (1993), who studied different concentrations of carboxymethyl cellulose (CMC), verified lower mineral absorption when the CMC levels in the feed for broilers was increased. Apparent digestibility coefficient of ash was positively correlated, whereas ADCCa was negatively correlated with ITT and IV. The decreased calcium utilization can be related to the increased viscosity because of jelly formation. This can be explained by the tridimensional structure of the jelly pectin, which is a sequence of two galacturonic acids situated parallel to the bond between calcium ion and the free carboxyls (Braudo, 1991).

In the growth phase, the high pectin levels in the feed continued to increase IV. However, differently from the results of the starter phase, the highest ITT and the lowest EMC values were estimated with 20.14 and $25.83 \mathrm{~g}$ pectin $/ \mathrm{kg}$ diet, respectively, explaining the absence of significant correlation between IV and ITT, and between IV and EMC, as well as the existence of moderate negative correlation of ITT with EMC. The decrease in ITT and the elevation in EMC with the ingestion of pectin levels above 3\% must be emphasized. Silva et al. (2010) observed that water intake in broilers at the growth phase increased with the ingestion of feed containing high pectin levels. Therefore, the ITT decrease and the EMC increase with $3 \%$ of pectin can be consequences of an increased water intake. However, some substances can alter motor, absorptive and secretory functions of the gastrointestinal tract, resulting in constipation or diarrhea, dehydration and malnutrition (Santos Júnior, 2003). Thus, high viscosity of digesta increases the secretion of endogenous water into the intestine (Choct, 1997). Therefore, the ingestion of feed with high pectin levels can cause the loss of tissue fluid to the intestine at the growth phase. 
Energy utilization of feed by broilers decreased as the pectin levels in the feed were increased. However, the highest values of AME, AMEn, ACM and ACMn were estimated using $11.84,14.91,0.22$ and $05.55 \mathrm{~g}$ pectin $/ \mathrm{kg}$ diet, respectively. Variation in ME values considering broiler age was also observed by Shires et al. (1987) for broiler strains fed diets based on canola and soybean meal. Those authors discussed that the low energy utilization of the feed was related to the decrease of digesta passage rate through the gastrointestinal tract (intake), which happens as animals grow old. Annison \& Choct (1992) also attributed the variation in metabolizable energy values to the age of birds and digesta passage rate for broilers fed cereal-based diets with a high fiber concentration. In this study, the values of AME, AMEn, ACM, and ACMn were positively correlated with ITT and negatively with IV. Still, some signs of difficult intestinal transit could be observed, such as distended crop filled with feed; and strong and frequent abdominal movements (these results were not measured). Then, the decrease of metabolizability and apparent energy coefficients at growth phase of broilers fed diets containing pectin can be explained by the lower passage rate of digesta and increase of IV. The differences observed in this experiment for AME, AMEn, ACM and ACMn between starter and growth phases according to the different pectin levels in the diet demonstrate that the effect of pectin ingestion depends on the quantity of this substance and the rearing phase.

As mentioned before, ADCCF was not influenced by the increase in pectin levels in the feed at the starter phase. However, this parameter decreased at the growth phase when fiber ingestion rose. These results are in agreement with Edney et al. (1989), who verified worse fecal digestibility of fat as IV increased. Decrease of lipid absorption can be partially explained by the retention of the biliar salts by soluble fibers, phospholipids and cholesterol (Vahouny et al. 1980). Isaksson et al. (1982) performed in vitro experiments and showed that fiber has more inhibitory effect on lipase than on other digestive enzymes. According to those authors, viscosity negatively affects the absorption rate of simple molecules instead of the whole quantity, and probably, the mechanism is different for each molecule. Moreover, larger particles such as micelles must have strong bindings and present higher resistance to intestinal peristaltism (Edwards et al., 1988).

Unlike the starter phase, growth phase presented decreased calcium absorption and improved ash utilization as pectin concentration increased. Still, the ingestion of $21.7 \mathrm{~g} \mathrm{pectin} / \mathrm{kg}$ diet increased phosphorus absorption, showing that improvement in ADCA can be explained by the higher absorption of other minerals, except calcium and phosphorus. These results are different from the study of Hetland \& Svihus (2001), who did not find effect of the different types of carbohydrates on ash digestibility. Van der Klis et al. (1993) studied concentrations of carboxymethyl cellulose and recorded low mineral absorption when these concentrations in the feed of broilers increased, also differing from this study. Similar to the starter phase, ADCA and ADCCa were positively and negatively correlated with IV at growth phase, respectively.

\section{Conclusions}

Pectin levels in the feed affect intestinal transit time, excreta moisture content and feed digestibility according to the developmental phase of the broiler. Intestinal viscosity increases as pectin ingestion increases. Intestinal transit time and intestinal viscosity have a higher influence on feed digestibility at growth than at the starter phase. Therefore, addition of pectin to the feed improves energy utilization of broilers at the starter phase.

\section{Acknowledgments}

We thank Fundação de Apoio à Pesquisa de São Paulo (FAPESP, Brazil) for the financial support (Proc. No. 07/59891-0) and Coordenação de Aperfeiçoamento de Pessoal de Nível Superior (CAPES, Brazil) for the student support.

\section{References}

ADRIZAL; OHTANI, S. Effects of rice bran-polysaccharides and fiber degrading enzymes on performance and nutrient digestibility in broiler chickens. Journal of Poultry Science, v.39, p.109-117, 2002.

AMIRKOLAIE, A.K.; LENHOUWERSM, J.I.M; VERRETH, A.J et al. Type of dietary fibre (soluble and unsoluble) influences digestion, faeces characteristics and faecal waste production in Nile tilapia (Oreochromis niloticus L.). Aquaculture Research, v.36, p.1157-1166, 2005.

ANNISON, G.; CHOCT, M. The anti-nutritive activities of cereal nonstarch polysaccharides in broiler diets and strategies minimizing their effects. World's Poultry Science Journal, v.47, p.232-242, 1992.

ANNISON, G.; CHOCT, M. Plant polysaccharides - fiber physicochemical properties and nutritional roles in the monogastric animals. In: LYONS, T.P.; JACQUES, K.A. (Eds). Biotechnology in the feed industry. Proceedings... Alltech's Tenth Annual Symp. Nottingham: Nottingham University Press, 1994. p.51-66.

BACH KNUDSEN, K.E. Carbohydrate and lignin contents of plant materials used in animal feeding. Animal Feed Science and Technology, v.67, p.319-338, 1997.

BARROW, P.A. Probiotics for chicken. In: FULLER, R. (Ed.) Probiotics: The scientific basis. London: Chapman and Hall, 1992. p.229-234. 
BENÍCIO, L.A.S. Restrição ao uso de aditivos (promotores de crescimento) em rações de aves - visão da indústria, São Paulo, SP, 1996. In: CONFERÊNCIA DE CIÊNCIA E TECNLOGIA AVÍCOLAS - APINCO, 1996, São Paulo. Anais... São Paulo: APINCO, 1996. p.17-26.

BRAUDO, E.E. Polyuronide interactions with polycoordinate metal íons. Food Hydrocolloids, v.5, p.75-85, 1991.

BURACZEWSKA, L.; ŚWIECCH, E.; TUŚNIO, A. et al. The effect of pectin on amino acid digestibility and digesta viscosity, motility and morphology of the small intestine, and on N-balance and performance of young pigs. Livestock Science, v.109, p.53-56, 2007.

CHOCT, M. Feed non-starch polysaccharides: chemical structures and nutritional significance. Feed Milling International, p.13-26, 1997.

CHOCT, M.; ANNISON, G. Anti-nutritive activity of wheat pentosans in broiler diets. British Poultry Science, v.3, p.821-821, 1990.

CHOCT, M.; HUGHES, R.J.; WANG, J. et al. Increased small intestinal fermentation is partly responsible for the anti-nutritive activity of non-starch polysaccharides in chickens. British Poultry Science, v.37, p.609-921, 1996.

CONTE, A.J.; TEIXEIRA, A.S.; FIALHO, E.T. et al. Efeito da fitase e xilanase sobre o desempenho e as características ósseas de frangos de corte alimentados com dietas contendo farelo de arroz. Revista Brasileira de Zootecnia, v.32, p.1147-1156, 2003.

CÓRDOVA, K.R.V.; GAMA, T.M.M.T.B.; WINTER, C.M.G. et al. Características físico-químicas da casca do maracujá amarelo (Passiflora edulis Flavicarpa Degener) obtida por secagem. Boletim do CEPPA, v.23, p.221-230, 2005.

DOESCHATE, R.A.H.M.; SCHEELE, C.W.; SCHREURS, V.V.A.M. et al. Digestibility studies in broilers chickens: influence of genotype, age, sex and method of determination. British Poultry Science, v.34, p.131-146, 1993.

EDNEY, M.J.; CAMBELL, G.L.; CLASSEN, H.L. The effect of $\beta$-glucanase supplementation on nutrient digestibility and growth in broilers given diets containing barley, oats groats or wheat. Animal Feed Science and Technology, v.25, p.193-200, 1989.

EDWARDS, C.A.; JOHNSON, L.L.; READ, N.W. Do viscous polysaccharides slow absorption by inhibiting diffusion or convection? European Journal of Clinical Nutrition, v.42, p.307-312, 1988 .

EUFRÁSIO, M.R.; BARCELOS, M.F.P.; SOUSA, R.V. et al. Efeito de diferentes tipos de fibras sobre frações lipídicas do sangue e fígado de ratos wistar. Ciência e Agrotecnologia, v.33, p.1608-1614, 2009.

FERREIRA, W.M. Os componentes da parede celular vegetal na nutrição de não ruminantes. In: SIMPÓSIO INTERNACIONAL DE PRODUÇÃO DE NÃO-RUMINANTES; REUNIÃO ANUAL DA SOCIEDADE BRASILEIRA DE ZOOTECNIA, 31., 1994, Maringá. Anais... Maringá: SBZ, 1994. p.85-113.

FIETZ, V.R.; SALGADO, M.S. Efeito da pectina e da celulose nos níveis séricos de colesterol e triglicerídeos em ratos hiperlipidêmicos. Ciência e Tecnologia dos Alimentos, v.19, p.3218-321, 1999.

FREIRE, J.P.B.; GUERREIRO, A.J.G.; CUNHA, L.F. et al. Effect of dietary fiber source on digestibility, caecum volatile fatty acids and digestive transit time in the weaned piglet. Animal Feed Science and Technology, v.87, p.71-83, 2000.

GUTKOSKI, L.C.; TROMBETTA, C. Avaliação dos teores de fibra alimentar e de beta-glicanas em cultivares de aveia (Avena sativa L). Ciência e Tecnologia dos Alimentos, v.19, p.387-390, 1999.

HETLAND, H.; SVIHUS, B. Effect of oat hulls on performance, gut capacity and feed passage time in broiler chickens source British Poultry Science, v.42, p.354-361, 2001.

HUANG, K.H.; RAVINDRAN, V.; LI, X. et al. Influence of age on the apparent ileal digestibility of feed ingredients for broiler chickens. British Poultry Science, v.46, p.236-245, 2005.

IDE, T.; HORRI, M.; KAWASHIMA, K. et al. Bile acid conjugation and hepatic taurine concentration in rats fed on pectin. British Journal of Nutrition, v.62, p.539-550, 1989.
IKEGAMI, S.; TSUCHIHASHI, F.; HARADA, H. et al. Effect of viscous indigestible polysaccharides on pancreatic-biliary secretion and digestive organs in rats. Journal of Nutrition, v.120, p.353-360, 1990.

ISAKSSON, G.; LUNDQUIST, I.; IHSE, I. Effect of dietary fiber on pancreatic enzyme activity in vitro; the importance of viscosity, $\mathrm{pH}$, ionic strength, adsorption, and time of incubation. Gastroenterology, v.82, p.918-924, 1982.

JIA, W.; SLOMINSKI, B.A.; BRUCE, H.L. et al. Effects of diet type and enzyme addition on growth performance and gut health of broiler chickens during subclinical Clostridium perfringens challenge. Poultry Science, v.88, p.132-140, 2009.

LANGHOUT, D.J.; SCHUTTE, J.B.; VAN LEEUWEN, P. et al. Effect of dietary high-and low-methylated citrus pectin on the activity of the ileal microflora and morphology of the small intestinal wall of broiler chicks British Poultry Science, v.40, p.340-347, 1999.

LARBIER, M.; LECLERQ, B. Nutrition and feeding of poultry. Nothingham: Nottingham University, 1994. 350p.

LEENHOUWERS, J.I.; ADJEI-BOATENG, D.; VERRETH, J.A.J. et al. Digesta viscosity, nutrient digestibility and organ weights in African catfish (Clarias gariepinus) fed diets supplemented with different levels of a soluble non-starch polysaccharide. Aquaculture Nutrition, v.12, p.111-116, 2006.

LEENHOUWERS, J.I.; ORTEGA, R.C.; VERRETH, J.A.J. et al. Digesta characteristics in relation to nutrient digestibility and mineral absorption in Nile tilapia (Oreochronis niloticus L.) fed cereal grains of increasing viscosity. Aquaculture, v.27, p.556-565, 2007.

MARTINS, J.M.; RIOTTO, T.M.; ABREU, M.C. et al. Cholesterollowering effects of dietary bllue lupin (Lupinus angustifolius L.) inintact and ileorectal anastomosed pigs. Journal of Lipid Research, v.46, p.1539-1547, 2005.

MATTERSON, L.D.; POTTER, L.M.; STUTZ, M.W. The metabolizable energy of feed ingredients for chickens. Storrs: University of Connecticut, Agricultural Experiment Station, 1965. 11p. (Research report, 7).

NIR, I. Mecanismos de digestão e absorção de nutrientes durante a primeira semana. In: CONFERÊNCIA APINCO DE CIÊNCIA E TECNOLOGIA AVÍCOLAS; SIMPÓSIO INTERNACIONAL SOBRE MANEJO DE PINTOS DE CORTE, 1998, Campinas. Anais... Campinas, 1998. p.121-139.

OLIVEIRA, M.C.; SICHIERI, R. Fracionamento das refeições e colesterol sérico em mulheres com dieta adicionada de frutas e fibras. Revista de Nutrição, v.17, p.449-459, 2004.

PINHÃO, R.L.; PAIVA, J.P.V.; TAVARES, F.M.M. et al. Valores séricos de glicose, triglicerídeos e colesterol em cães (canis familiaris) com sobrepeso, suplementados na dieta com fibra de maracujá (passiflora edulis). Revista Eletrônica Novo Enfoque, v.9, p.56-63, 2010.

RAMOS, A.T.; CUNHA, M.A.L.; SABAA-SRUR, A.U.O. et al. Uso de Passiflora edulis f. flavicarpa na redução do colesterol. Revista Brasileira de Farmacognosia, v.17, p.592-597, 2007.

ROSTAGNO, H.S.; ALBINO, L.F.T.; DONZELE, J.L. et al. Tabelas brasileiras para aves e suínos: composição de alimentos e exigências nutricionais. Viçosa, MG: Universidade Federal de Viçosa, 2005. 186p.

ROWE, J.B.; CHOCT, M.; PETHICK, D.W. Processing cereal grains for animal feeding. Australian Journal of Agriculture Research, v.50, p.721-736, 1999.

SANTOS JÚNIOR, J.C.M. Laxantes e purgativos: o paciente e a constipação intestinal. Revista Brasileira de Colo-proctologia, v.23, p.130-140, 2003.

SHAKOURI, M.D.; KERMANSHAHI, H.; MOHSENZADEH; M. Effect of different non starch polysaccharides in semi purified diets on performance and intestinal microflora of young broiler chickens International Journal of Poultry Science, v.5, p.557-561, 2006.

SHIRES, A.; THOMPSON, J.R.; TURNER, B.V. et al. Rate of passage of corn-canola and corn soybean meal diets through the gastrointestinal tract of broiler and White Leghorn chickens. Poultry Science, v.66, p.289-298, 1987. 
SILVA, D.J.; QUEIROZ, A.C. Análise de alimentos: métodos químicos e biológicos. 3.ed. Viçosa, MG: Universidade Federal de Viçosa, 2002. 235p.

SILVA, V.K.; MORITA, V.S.; MARTINS, M.S. et al. Ingestão de água e ração por frangos de corte alimentados com ração contendo diferentes níveis de pectina In: PRÊMIO LAMAS 2010, Campinas. Anais... Santos: Fundação Avícola de Ciência e Tecnologia Avícolas, 2010. (CD-ROM).

SKLAN, D.; SMIRNOV, A.; PLAVNIK, I. The effect of dietary fiber on the small intestines and apparent digestion in the turkey. British Poultry Science, v.44, p.735-740, 2003.

SMITS, C.H.; VELDMAN, A.; VERKADE, H.J. et al. The inhibitory effect of carboxymethylcellulose with high viscosity on lipid absorption in broiler chickens coincides with reduced bile salt concentration and raised microbial numbers in the small intestine. Poultry Science, v.77, p.1534-1539, 1998.
VAHOUNY, G.V.; TOMBES, R.; CASSIDY, M.M. et al. Dietary fibres: V. binding of bile salts, phospholipids and cholesterol from mixed micelles by bile acid sequestrants and dietary fibres. Lipids, v.15, p.1012-1018, 1980.

VAN DER KLIS, J.D.; VERSTEGEN, M.W.; VAN VOORST, A. Effect of a soluble polysaccharide (carboxy methyl cellulose) on the absorption of minerals from the gastrointestinal tract of broilers. British Poultry Science, v.34, p.985-997, 1993.

WANGER, D.D; THOMAS, O.P. Influence of diets containing rye or pectin on the intestinal flora of chicks Poultry Science, v.57, p.971-975, 1978.

WENK, C. The role of dietary fiber in the digestive physiology of pig. Animal Feed Science and Technology, v.90, p.21-33, 2001.

VERGARA, P.; JIMENEZ, M.; FERRANDO, C. et al. Age influence on digestive transit time of particulate and soluble markers in broiler chickens. Poultry Science, v.68, p.185-189, 1989. 